Scholarship Repository

University of Minnesota Law School

Articles

Faculty Scholarship

1982

\title{
A New United Nations Mechanism for Encouraging the Ratification of Treaties
}

David Weissbrodt

University of Minnesota Law School, weiss001@umn.edu

Follow this and additional works at: https://scholarship.law.umn.edu/faculty_articles

Part of the Law Commons

\section{Recommended Citation}

David Weissbrodt, A New United Nations Mechanism for Encouraging the Ratification of Treaties, 4 Hum. RTS. Q. 333 (1982), available at https://scholarship.law.umn.edu/faculty_articles/218.

This Article is brought to you for free and open access by the University of Minnesota Law School. It has been accepted for inclusion in the Faculty Scholarship collection by an authorized administrator of the Scholarship Repository. For more information, please contact lenzx009@umn.edu. 


\section{A New United Nations Mechanism for Encouraging the Ratification of Treaties}

\section{David Weissbrodt}

\section{INTRODUCTION}

The ratification of international human rights treaties is critical to the worldwide observance of human rights and fundamental freedoms. The United Nations General Assembly and Commission on Human Rights have repeatedly emphasized the importance of ratification and have frequently encouraged states to ratify the relevant international instruments. Despite these efforts, acceptance of human rights treaties has been uneven. A considerable number of states have failed to ratify.

Recognizing that a regular mechanism for encouraging ratification would be more effective than general exhortations, the Sub-Commission on Prevention of Discrimination and Protection of Minorities, a subsidiary body of the Commission on Human Rights, established a sessional working group in 1979 to consider ways and means of encouraging acceptance of human rights treaties. The procedures of the Working Group on the Encouragement of Universal Acceptance of Human Rights Instruments were modeled on the highly successful methods used by the International Labour Organisation (ILO) to encourage its members to accede to labor standards. In 1980 and 1981 the Working Group began by considering systematically the written explanations of governments as to impediments they had encountered in ratifying human rights treaties and by receiving representatives from several countries to discuss these difficulties.

This article will discuss the rationale for the establishment of the Working Group, its accomplishments thus far, and recent debate concerning the Group's scope of authority. Finally, suggestions will be made for future objectives on which the Group may profitably focus.

The author is very grateful for the assistance of Patricia A. Moses in preparing this article. A shortened version of this article appeared in 76 AM. J. INT' L. 418 (1982). 


\section{IMPORTANCE OF ENCOURAGING RATIFICATION}

In keeping with its mandate to promote universal respect for human rights, the General Assembly has promulgated over thirty-five standard-setting treaties which set forth obligations to be undertaken by ratifying countries for ensuring the observance of human rights.' Articles 1, 55, and 56 of the United Nations Charter grant the Assembly the power to adopt human rights treaties. The encouragement of ratification and accession to human rights instruments is a vitally important next step to ensuring the broadest international respect for human rights.

The General Assembly acknowledged in 1977 the progress achieved by the international community in promoting human rights and fundamental freedoms, particularly with respect to the standard-setting work of the United Nations. ${ }^{2}$ Because acceptance by member states of the obligations contained in international instruments is an important element for universal implementation of human rights, the General Assembly decided that future work of the United Nations should recognize that:

It is of paramount importance for the promotion of human rights and fundamental freedoms that member States undertake specific obligations through accession to or ratification of international instruments in this field; consequently the standard setting work within the United Nations system in the field of human rights and the universal acceptance and implementation of the relevant international instruments should be encouraged. ${ }^{3}$

The importance of encouraging ratification of international human rights treaties is not a new concept to the United Nations. The General Assembly and the Commission on Human Rights have urged member states to accept the instruments on numerous occasions. For example, the General Assembly has regularly called for ratification of the International Convention on the Elimination of All Forms of Racial Discrimination; ${ }^{4}$ the International Covenant on Economic, Social and Cultural Rights; the International Cove-

1. See Human Rights: A Compilation of International Instruments, U.N. Doc. ST/HR/Rev. 1 (1978).

2. G.A. Res. 32/130, 32 U.N. GAOR, Supp. (No. 45) 150, U.N. Doc. A/32/45 (1977).

3. Id. The General Assembly has since reaffirmed resolution $32 / 130$, again emphasizing the importance of member states' acceptance of obligations to ensure respect for human rights and reiterating that implementation and acceptance should be encouraged. G.A. Res. 34/46, 34 U.N. GAOR, Supp. (No. 46) 170, U.N. Doc. AJ34/46 (1979); G.A. Res. 35/174 (1981); see also U.N. Doc. AVRES/35/174 (1981).

4. G.A. Res. 3225, 29 U.N. GAOR, Supp. (No. 31) 86, U.N. Doc. A/9631 (1974); G.A. Res. 3266, 29 U.N. GAOR, Supp. (No. 31) 87, U.N. Doc. A/9631 (1974); G.A. Res. 3381, 30 U.N. GAOR, SUpp. (No. 34) 84, U.N. Doc. A/10034 (1975); G.A. Res. 31/79, 31 U.N. GAOR, Supp. (No. 39) 99, U.N. Doc. A/31/39 (1976); G.A. Res. 32/13, 32 U.N. GAOR, Supp. (No. 45) 132, U.N. Doc. A/32/45 (1977); G.A. Res. 32/11, 32 U.N. GAOR, Supp. (No. 45) 131 U.N. Doc. A/32/45 (1977); G.A. Res. 33/101, 33 U.N. GAOR, Supp. (No. 45), U.N. Doc. A/33/45 (1978): G.A. Res. 34/26, 34 U.N. GAOR, Supp. (No. 46) 165, U.N. 
nant on Civil and Political Rights; and the Optional Protocol to the International Covenant on Civil and Political Rights; ${ }^{5}$ the International Convention on the Suppression and Punishment of the Crime of Apartheid; ${ }^{6}$ and the Convention on the Elimination of All Forms of Discrimination Against Women.7 Similarly, the Commission on Human Rights has encouraged member states to ratify various treaties. ${ }^{8}$

However, despite the frequency and eloquence of these urgings, ratifications continue at a moderate pace. Of the more than 150 members of the United Nations, only 67 states have acceded to the International Covenant on Civil and Political Rights, ${ }^{9}$ only 69 have ratified the International Covenant on Economic, Social and Cultural Rights, ${ }^{10}$ and only 26 have ratified the Optional Protocol to the International Covenant on Civil and Political Rights " in the 14 years since these instruments were adopted by the General Assembly. Similarly, while 84 states have ratified (and 4 states have signed) the Genocide Convention, over 65 states have not taken action

Doc. A/34/46 (1979); G.A. Res. 34/28, 34 U.N. GAOR, Supp. (No. 46) 166, U.N. Doc. A/34/46 (1979); see also G.A. Res. $35 / 38$ U.N. Doc. A/RES/35/38 (1980); G.A. Res. 35/40, U.N. Doc. ARES/35/40 (1980).

5. G.A. Res. 3270, 29 U.N. GAOR, Supp. (No. 31) 90, U.N. Doc. A/9631 (1974); G.A. Res. 31/86, 31 U.N. GAOR, Supp. (No. 39) 103, U.N. Doc. A/31/39 (1976); G.A. Res. 32/66, 32 U.N. GAOR, Supp. (No. 45) 138, U.N. Doc. A/32/45 (1977); G.A. Res. 33/51, 33 U.N. GAOR, Supp. (No. 45), U.N. Doc. A/33/45 (1978); G.A. Res. 34/45, 34 U.N. GAOR, Supp. (No. 46) 169, U.N. Doc. A/34/46 (1979); see also G.A. Res. 35/132, U.N. Doc. A/RES/35/132 (1981).

6. G.A. Res. 34/27, 34 U.N. GAOR, Supp. (No. 46) 165, U.N. Doc. A/34/46 (1979).

7. See G.A. Res. 35/140, U.N. Doc. A/RES/35/140 (1980).

8. Encouraging ratification of the International Convention on the Suppression and Punishment of the Crime of Apartheid: Human Rights Comm'n Res. 6, 37 U.N. ESCOR, Supp. (No. 5) 201, U.N. Doc. E/CN.4/1475 (1981); Human Rights Comm'n Res. 12, 36 U.N. ESCOR, Supp. (No. 3) 172, U.N. Doc. E/CN.4/1408 (1980); Human Rights Comm'n 13, 36 U.N. ESCOR, Supp. (No. 3) 173, U.N. Doc. E/CN.4/1408 (1980); Human Rights Comm'n Res. 7, 34 U.N. ESCOR, Supp. (No. 4) 110, U.N. Doc. E/CN.4/1292 (1978). Encouraging ratification of the international Covenant on Economic, Social and Cultural Rights, the International Covenant on Civil and Political Rights, and the Optional Protocol to the International Covenant on Civil and Political Rights: Human Rights Comm'n Res. 16, 37 U.N. ESCOR, Supp. (No. 5) 218, U.N. Doc. E/CN.4/1475 (1981); Human Rights Comm'n Res. 8, 36 U.N. ESCOR, Supp. (No. 3) 166, U.N. Doc. E/CN.4/1408 (1980); Human Rights Comm'n Res. 9, 34 U.N. ESCOR, Supp. (No. 4) 113, U.N. Doc. E/CN.4/1292 (1978); Human Rights Comm'n Res. 2, 33 U.N. ESCOR, Supp. (No. 6) 71, U.N. Doc. E/CN.4/1257 (1977).

U.N. bodies have not only adopted general hortatory resolutions encouraging states to ratify human rights treaties, the Sub-Commission on the Prevention of Discrimination and Protection of Minorities also encouraged ratification of the Supplementary Convention on the Abolition of Slavery, the Slave Trade, and Institutions and Practices Similar to Slavery of 1958 , by requesting the Secretary-General to send a separate note verbale to each state which had not yet become a party. See U.N. Doc. E/CN.4/Sub.2/AC.2/40 (1981).

9. Multilateral Treaties in Respect of Which the Secretary-Ceneral Performs Depositary Functions: List of Signatures, Ratifications, Accessions, etc. as of 31 December 1979, U.N. Doc. ST/LEG/SER.D/13 at 111 (1980). These figures have been updated through 15 June 1981, by reference to U.N. Doc. E/CN.4/Sub.2/463 (1981).

10. U.N. Doc. E/CN.4/Sub.2/463 at 2 (1981).

11. Id. 
toward ratification in the 32 years since the treaty was adopted. ${ }^{12}$ Clearly the goals of widespread ratification and implementation of human rights treaties cannot be reached by relying on general resolutions requesting ratification.

\section{ESTABLISHMENT OF THE WORKING GROUP}

In pursuit of a more effective approach to achieving broad ratification, the Sub-Commission on Prevention of Discrimination and Protection of Minorities at its thirty-second session in 1979 established the Working Group on the Encouragement of Universal Acceptance of Human Rights Instruments. ${ }^{13}$

Prior to the adoption of the resolution, Sub-Commission members expressed general support for a systematic mechanism to encourage ratifications. Three Sub-Commission members, Raul Ferrero of Peru, Ahmed Khalifa of Egypt, and Nicole Questiaux of France, initiated the resolution ${ }^{14}$ which was applauded by the Sub-Commission as innovative and constructive. ${ }^{15}$ Some Sub-Commission members, however, felt that the provisions directing the Working Group to request information from governments and to invite representatives to appear before it for clarification were beyond the Sub-Commission's terms of reference. On a motion by the Soviet expert to delete those provisions, the Sub-Commission retained the disputed provisions in an evenly divided vote. The resolution itself was overwhelmingly approved by the Sub-Commission by a vote of seventeen to two, with two abstentions. ${ }^{16}$

The Working Group is to function during regular Sub-Commission sessions to avoid the expense of presessional meetings. The Sub-Commission gave the Working Group a three-fold mandate: 1) to request, through the Secretary-General, governments which had not yet ratified the principal instruments to inform the Sub-Commission of circumstances or difficulties which prevented ratification; 2 ) to examine replies and to invite representatives from these governments to appear before the Working Group to clarify their replies; and 3) to consider what assistance the United Nations may offer to enable them to ratify as soon as possible.

12. Id.; see also Human Rights International Instruments, U.N. Doc. ST/HR/4/Rev.2 (1980) (ratifications, etc. as of 1 January 1980).

13. Report of the Sub-Commission on Prevention of Discrimination and Protection of Minorities on its Thirty-second Session, Res. 1 B (XXXII), U.N. Doc. E/CN.4/1350 (1979).

14. U.N. Doc. E/CN.4/Sub.2/L.716 (1979).

15. Eight nongovernmental organizations submitted a statement to the Sub-Commission supporting the establishment of the Working Group and stressing the need for improved methods of encouraging ratification of human rights treaties. U.N. Doc. E/CN.4/Sub.2/NGO/80 and Add. 1 (1979).

16. Jose Martinez Cobo of Ecuador and Dumitru Ceausu of Romania voted against the resolution. Mario Amadeo of Argentina and Hicri Fisek of Turkey abstained. 
The resolution enumerates human rights instruments which will receive the Group's attention. These include the International Covenant on Economic, Social and Cultural Rights, the International Covenant on Civil and Political Rights, the Optional Protocol to the International Covenant on Civil and Political Rights, the International Convention on the Elimination of All Forms of Racial Discrimination, the International Convention on the Suppression and Punishment of the Crime of Apartheid, the Slavery Convention, the Protocol amending the Slavery Convention, the Supplementary Convention on the Abolition of Slavery, the Slave Trade and the Institutions and Practices similar to Slavery, and such other instruments as may be designated by the Sub-Commission.

In accordance with the resolution, the Secretary-General requested governments which had not ratified the treaties to forward relevant information about circumstances which had so far prevented or delayed acceptance. ${ }^{17}$ The Sub-Commission informed the Commission on Human Rights of the creation of the sessional Working Group at the Commission's thirty-sixth session. ${ }^{18}$ The Commission offered no objection, taking note of the SubCommission's report without a vote. ${ }^{19}$

The Working Group on the Encouragement of Universal Acceptance of Human Rights Instruments held its first meeting during the thirty-third session of the Sub-Commission in fall 1980. During the interim twenty countries responded to the Secretary-General's initial request for information. The Working Group examined these replies and heard oral clarifications from the representatives of Australia, France, and the Netherlands. ${ }^{20}$

In the course of the meetings, some members of the Working Group debated the Group's competence to request information and to invite representatives to appear. The Office of Legal Affairs of the United Nations issued an opinion determining that the Working Group's authority to solicit information and to invite representatives to appear was inherent in the SubCommission's mandate to initiate studies and make recommendasions. The Office of Legal Affairs reasoned that power to gather and collect information was a prerequisite to fulfilling the Sub-Commission's purpose of undertaking studies concerning the prevention of discrimination and protection of

17. Note Verbale by the Secretary-General, U.N. Ref. No. G/SO 234 (17-4) (1979).

18. Report of the Sub-Commission on Prevention of Discrimination and Protection of Minorities on its Thirty-second Session, U.N. Doc. E/CN.4/1350 (1979), considered at the Commission's 1559th to 1563rd meetings.

19. Human Rights Comm'n Dec. 7, 36 U.N. ESCOR, Supp. (No. 3) 202, U.N. Doc. E/CN.4l 1408 (1980). The Director of the Human Rights Division Theo van Boven considered the creation of the Working Group sufficiently important to give some prominence to its establishment in his report of 18 March 1980, to the Human Rights Committee. U.N. Doc. CCPR/C/SR.196 at 4 (1980).

20. Report of the Sessional Working Group on the Encouragement of Universal Acceptance of Human Rights Instruments, U.N. Doc. E/CN.4/Sub.2/453 (1980). 
minorities. ${ }^{21}$ The Working Group decided that it had the authority to adhere to its mandate. Doubtful members were reminded that the Group had no power in any case to force governments either to accede to instruments or to accept the Group's invitation to appear.22

The Working Group reported to the Sub-Commission that the observer from France challenged the authority of the Group, but nevertheless expressed his government's readiness to cooperate. ${ }^{23}$ The representative from the Netherlands, while observing that his government did not feel obliged to appear, praised the Group's establishment "as a viable means of trying to get as many countries as possible to ratify human rights instruments." He suggested that the Group's mandate be expanded to include the encouragement of the goals contained in General Assembly declarations which had not yet become conventions. ${ }^{24}$

The representatives who appeared before the group explained the situations in their respective countries which created obstacles to ratification. A common difficulty encountered by the States concerned the question of extraterritorial criminal responsibility arising from the Convention on Apartheid. ${ }^{25}$ The Working Group ended the session with plans to discuss the designation of additional instruments for the Group's attention at the next session. The Sub-Commission took note of the Working Group's report and decided to allot more time to the activities of the Working Group in future sessions. The Sub-Commission requested the Secretary-General to make a study of the extraterritorial criminal responsibility issue. ${ }^{26}$

\section{SCOPE OF AUTHORITY OF THE WORKING GROUP}

The report of the Sub-Commission received close attention at the thirtyseventh session of the Commission on Human Rights in early 1981 and was the subject of considerable debate. ${ }^{27}$ The representative from Brazil, Jardim Gagliardi, criticized the Sub-Commission for exceeding its terms of

21. Report of the Sub-Commission on Prevention of Discrimination and Protection of Minorities on its Thirty-third Session, U.N. Doc. E/CN.4/1413, Annex at 53 (1980).

22. Id.

23. Id. at 51 . Interestingly, Questiaux of France had been a sponsor of the initial resolution in 1979. See U.N. Doc. E/CN.4/Sub.2/L.716 (1979). Also, Joinet, who was Questiaux's alternate in 1981, spoke at the Working Group emphatically against his government's previous position, participated in the Working Group's meetings, even though he was not a member, and co-sponsored the Working Group's resolution 19 in the Sub-Commission. See U.N. Doc. E/CN.4/Sub.2/L.790 (1981).

24. Id. at 52.

25. See Note by the Secretary-General containing a summary of information submitted by Governments, U.N. Doc. E/CN.4/Sub.2/452 and Adds. 1. 2 (1980).

26. Report of the Sub-Commission on Prevention of Discrimination and Protection of Minorities on its Thirty-third Session. U.N. Doc. E/CN.4/1413 at 84-85 (1980).

27. 37 U.N. ESCOR, Supp. (No. 5) 160, U.N. Doc. E/CN.4/1475 (1981). 
reference. ${ }^{28} \mathrm{He}$ assailed the Sub-Commission's direct communications with member states as well as its passage of recommendations which had a budgetary impact, but which had not been authorized by the Commission and ECOSOC. In his view the Sub-Commission should have submitted many of its recommendations for prior approval. Gagliardi dismissed as insufficient the opinion of the Office of Legal Affairs which affirmed the authority of the Working Group on the Encouragement of Universal Acceptance of Human Rights Instruments. He charged that the opinion implicitly expanded the Sub-Commission's terms of reference. The Polish and Bulgarian ${ }^{29}$ delegates vocally supported the Brazilian's view. ${ }^{30}$

Some representatives countered this attack and commended the SubCommission on its substantial contributions to the human rights field. ${ }^{31}$ Specifically, representatives from Canada ${ }^{32}$ and Denmark ${ }^{33}$ welcomed the establishment of the Working Group, noting the useful dialogue that had already been opened with member states on difficulties encountered with ratification.

After this debate, the Commission adopted a resolution which reaffirmed the Sub-Commission's significant role. The Commission, however, requested the Sub-Commission to bear in mind its assigned tasks under the relevant ECOSOC or Commission resolutions and invited it to take note of the comments and suggestions made during the discussion of the SubCommission's report. The Commission assigned high priority in future sessions to the report of the Sub-Commission and the recommendations contained therein. Additionally, it requested that the Sub-Commission specify clearly in its reports which matters required approval by the Commission and determined that the Secretary-General would bring these particular concerns to the attention of the Commission prior to each session. ${ }^{34}$

28. See Summary Record of the 1592nd Meeting, U.N. Doc. E/CN.4/SR.1592 at 5-10 (1981).

29. Summary Record of the 1594th Meeting, U.N. Doc. E/CN.4/SR.1594, at 3, 8 (1981).

30. Other delegates agreed that to some extent the Sub-Commission had been excessive. Some of its resolutions required financial commitments and affirmative positions which were not properly brought to the attention of the Commission for authorization. Delegates pointed to Sub-Commission Resolution 19 (XXXIII) which recommended the establishment of an information gathering service on human rights and observed that ECOSOC must authorize such a system. Resolution 22 (XXXIII) requested the Commission to authorize Sub-Commission members to go on fact-finding missions to any countries which were the subject of discussion at the Sub-Commission's 33rd session. Such recommendations, it was claimed, were beyond the scope of the Sub-Commission's proper concern and, perhaps, would infringe on the domestic jurisdiction of governments.

31. E.g., remarks of Max van der Stoel, the representative from the Netherlands, Summary of the Record of the 1594th Meeting, U.N. Doc. E/CN.4/SR.1594 at 2; remarks of Jose D. Ingles of the Philippines, Id. at 7.

32. Summary Record of the 1593rd Meeting, U.N. Doc. E/CN.4/SR.1593 at 9 (1981).

33. Id. at 11-12.

34. Human Rights Comm'n Res. 17, 37 U.N. ESCOR, Supp. (No. 5) 219, U.N. Doc. E/CN.4/1475 (1981); see Summary Record of the 1635th Meeting, U.N. Doc. E/CN.4/SR.1635 at 8-11 (1981). 
The Commission's resolution was an expression of support for the work of the Sub-Commission, as is evidenced by the amount of attention paid to it and the decision to allocate high priority to the Sub-Commission's reports and recommendations. Although the Commission requested the SubCommission to note the controversy surrounding the issue of competence, it did not take steps to delimit or redefine the Sub-Commission's terms of reference. 35

The Working Group and the Sub-Commission in its August-September 1981 session properly took note of the concerns raised by Commission members. The Sub-Commission reaffirmed its right to communicate directly with member states on human rights issues, as it had done for many years without objection from the Commission. The Working Group met for six sessions. It carefully continued its country-by-country review of governmental replies, discussed the adequacy of the replies from the point of view of completeness and substance, and invited Sweden and Syria to participate in its deliberations. ${ }^{36}$ Neither Sweden nor Syria interposed any objections.

Based upon the recommendations of the Working Group, the SubCommission adopted a resolution by a vote of twenty in favor, none against, with only the Soviet expert abstaining, calling on the Secretary-General to renew the requests of 1979 and 1980 for governments to explain their difficulties in ratifying the principal human rights treaties. ${ }^{37}$ The Sub-Commission requested that the Secretary-General individualize the notes verbales to particular governments by drawing attention to specific treaties each government has not yet ratified. ${ }^{38}$ The Sub-Commission's resolution also requested that the Secretary-General invite the governments of the Philippines,

35. Also at the 37th session the Commission considered the Draft Medium-Term Plan for the Human Rights Programme for the Period 1984-1989 which was submitted for comment by the Secretary-General. Note by the Secretary-General, Review of the Draft MediumTerm Plan for the Period 1984-1989, U.N. Doc. E/CN.4/1424, Annex (1980). In setting out the general orientation of the program, the drafters recognized that universal acceptance of human rights standard-setting instruments should be encouraged and that "[i]t may be expected that useful contributions to the further ratification of international instruments will be made by the Sub-Commission's Working Group on the ratification of international standards in the field of human rights." Id. at 3. The Commission decided to take note of the draft medium-term plan and invited the Secretariat to bear in mind the observations made by members which largely involved technical and administrative issues. Human Rights Comm'n, Dec. 9, 37 U.N. ESCOR. Supp. (No. 5) 246, U.N. Doc. E/CN.4/1475 (1981).

36. Report of the Sessional Working Group on the Encouragement of Universal Acceptance of Human Rights Instruments, U.N. Doc. E/CN.4/Sub.2/L.785 (1981).

37. Draft Report of the Sub-Commission on Prevention of Discrimination and Protection of Minorities to the Commission on Human Rights on its Thirty-fourth Session, Res. 19, U.N. Doc. E/CN.4/Sub.2/(XXXIV)/CRP.2 at 113 (1981); see also U.N. Doc. E/CN.4/Sub.2/L.790 (1981) (draft resolution submitted by five members of the Sub-Commission: Bossuyt of Belgium, Jimeta of Nigeria, Joinet of France, Masud of India, and Tosevski of Yugoslavia. Oyhnarte of Argentina was the only member of the Working Group who did not join in sponsoring the resolution).

38. Governments such as the United States which have signed but not ratified many of the principal human rights treaties will be asked about the difficulties they may face in obtain- 
Rwanda, Iran, the Solomon Islands, and Surinam to supply additional information because the Working Group was not satisfied by the previous responses from those countries. The Sub-Commission resisted efforts to expand the mandate of the Working Group to include other human rights treaties, deciding to reconsider this issue at its next session. ${ }^{39}$

The Working Group continued its work with the support of the SubCommission. Several governments, including Australia, which had appeared before the Working Group in 1980, had ratified the human rights instruments by 1981 . While the Working Group has not yet generated the sort of substantive discussion of general ratification problems which one might expect in the future, the Working Group has begun to establish itself as an innovative mechanism for achieving the ratification and, ultimately, the implementation of human rights standards.

\section{LEGITIMACY OF THE WORKING GROUP}

Jardim Gagliardi, the Brazilian delegate to the 1981 session of the Commission on Human Rights, called into question the very heart of the Working Group's mandate: the mechanism for soliciting information from nonratifying states. This challenge to the Sub-Commission's competence presents two issues. First, is the Sub-Commission specifically authorized by its terms of reference to communicate directly with nonratifying governments to encourage the ratification of particular human rights conventions? Second, should an international organization be involved with encouraging ratification of its treaties and, if so, to what extent?

ing ratification. U.N. Doc. E/CN.4/Sub.2/L.785 at 6 (1981). See Weissbrodt, United States Ratification of the Human Rights Covenants, 63 MiNN. L. REv. 35. 35, 37 (1978).

39. In 1981 the Working Group discussed the possibility of adding three more treaties to its mandate: the International Convention against the Taking of Hostages, the Convention on the Elimination of All Forms of Discrimination Against Women, and the Convention for the Suppression of the Traffic in Persons and of the Exploitation of the Prostitution of Others. See U.N. Doc. E/CN.4/Sub.2/L.785, at 3 (1981); U.N. Doc. E/CN.4/Sub.2/NGO/87 (1981). (recommendation of several nongovernmental organizations that the Convention on the Elimination of All Forms of Discrimination Against Women be included within the Working Group's purview). The Working Group, however, resisted the addition of these new instruments because it felt that the Group should concentrate its efforts to be effective. Several members of the Working Group noted that the hostage and women's treaties had been adopted in 1979 and had not come into force. Accordingly it might be premature to direct special attention so soon. In addition, most of the treaties already within the Working Group's mandate had been drafted by the U.N. Commission on Human Rights and therefore fell particularly within the Sub-Commission's concern. None of the three proposed additional treaties had been formulated by the Human Rights Commission. Ultimately the initial list of treaties for Working Group attention was established by a consensus of the Sub-Commission as to the importance of the treaties and the need to concentrate on a few instruments to be effective. The Working Group concluded that it was just beginning its efforts and should restrict its attention rather than broaden its mandate at this early stage. 


\section{A. Direct Communication with States}

As to the first issue, Gagliardi asserted that direct communication with states is outside the Sub-Commission's competence. Its terms of reference, however, seem to contemplate the receipt of information from governments. The Sub-Commission's mandate, as established in 1948 and expanded in 1949 by the Commission, is:

(a) To undertake studies, particularly in the light of the Universal Declaration of Human Rights and to make recommendations to the Commission on Human Rights concerning the prevention of discrimination of any kind relating to human rights and fundamental freedoms and the protection of racial, national, religious and linguistic minorities; and (b) To perform any other functions which may be entrusted to it by the Economic and Social Council or the Commission on Human Rights. 40

The subject matter of the Working Group's mandate is undoubtedly within the Sub-Commission's terms of reference. The obligations contained in the human rights treaties are designed to ensure universal respect for and observance of human rights. Periodic requests for information, analyses of responses, and offers of technical assistance encourage states to become parties to human rights treaties and to notify and consult with the United Nations on problems which impede ratification.

In response to these criticisms the Director of the U.N. Human Rights Division ${ }^{41}$ noted the 1962 Advisory Opinion of the International Court of Justice in regard to Certain Expenses of the United Nations, ${ }^{42}$ which provides some guidance as to the authority of the Sub-Commission to encourage the ratification of human rights treaties and to communicate directly with governments. In determining whether peacekeeping expenses were improperly incurred by the United Nations, the Court first considered

40. 9 U.N. ESCOR, Supp. (No. 10) 6, U.N. Doc. E/CN.4/350 (1949). Resolution 8 (XXIII) of the Commission on Human Rights requested the Sub-Commission to prepare a report on violations of human rights and to bring to the attention of the Commission any situations which reveal a consistent pattern of violations. Human Rights Comm'n, Res. 8, 23 U.N. ESCOR, Supp. (No. 6) 131, U.N. Doc. E/CN.4/940 (1967). ECOSOC subsequently endorsed this extension of the Sub-Commission's mandate in E.S.C. Res. 1235, 42 U.N. ESCOR, Supp. (No. 1) 17, U.N. Doc. E/4393 (1967), and in E.S.C. Res. 1503, 48 U.N. ESCOR, Supp. (No. 1A) 8, U.N. Doc. E/4832/ Add.1 (1970) the Council established procedures for examining communications regarding violations of human rights and fundamental freedoms. In addition, the parent bodies occasionally request the SubCommission to carry out specific studies. For example at its 36th Session the Commission requested the Sub-Commission to prepare a study on ways and means of ensuring the implementation of United Nations resolutions on apartheid, racism and racial discrimination. E.S.C. Res. 14 D, 36 U.N. ESCOR, Supp. (No. 3) 176, U.N. Doc. E/CN.4/1408 (1980).

41. U.N. Doc. E/CN.4/SR.1595, at 8, 9 (1981); see United Nations Division of Human Rights, The Role and Competence of the Sub.Commission on Prevention of Discrimination and Protection of Minorities 20 (15 June 1981) (internal, unpublished memorandum).

42. Advisory Opinion on Certain Expenses of the United Nations, [1962] I.C.J. 151. 
whether the peacekeeping activity was unauthorized by the Charter. The Court responded:

In the legal systems of States, there is often some procedure for determining the validity of even a legislative or governmental act, but no analogous procedure is to be found in the structure of the United Nations. Proposals made during the drafting of the Charter to place the ultimate authority to interpret the Charter in the International Court of Justice were not accepted; the opinion which the Court is in course of rendering is an advisory opinion. As anticipated in 1945, therefore, each organ must, in the first place at least, determine its own jurisdiction. ${ }^{43}$

The Director suggested that this reasoning supports the Sub-Commission's determination of its own jurisdiction in fulfillment of its mandate to promote human rights. However, because the International Court of Justice (ICJ) was discussing the legal authority of the principal organs of the United Nations - the General Assembly, the Security Council, and the SecretaryGeneral. - there is some doubt that such broad self-interpretation of jurisdiction would apply to the Sub-Commission.

A better argument may be that the parent organs of the SubCommission - the Commission on Human Rights and ECOSOC - have not altered the broad mandate of the Sub-Commission although they possess the authority to do so. Because no express limits have been placed on the right of the Sub-Commission to promote human rights, and because the SubCommission has established a long, uncriticized practice of pursuing similar activities, it may well be entitled under the reasoning of the $[\mathrm{CJ}$ advisory opinion to interpret its own mandate.

To fulfill its mandate, the Sub-Commission must be able to gather and collect information. Indeed, such authority is fundamental if the SubCommission is to produce reliable studies from which recommendations can be made without considerable delay and diversion. The establishment of the Working Group represents the Sub-Commission's effort to organize its work as efficiently as possible. Such an internal procedural matter has always been within the competence of the Sub-Commission. ${ }^{44}$

Requesting information directly from member states is a common practice for the Sub-Commission in particular and for the United Nations in general. The Sub-Commission has long studied human rights issues by means of inquiries to governments. ${ }^{45}$ For example, in 1954 the Special Rap-

43. Id. at 168.

44. See Rules of Procedure of the Functional Commissions of the Economic and Social Council, rules 21, 24, U.N. Doc. E/5975 at 6-7 (1977) [hereinafter cited as Functional Rules].

45. See, e.g., Krishnaswami, Study of Discrimination in the Matter of Religious Rights and Practices, U.N. Doc. E/CN.4/Sub.2/200/Rev. 1 at 76 (1960); Santa Cruz, Study of Discrimination in the Matter of Political Rights, U.N. Doc. E/CN.4/Sub.2/213/Rev. 1, at 100-01 (1962); Saario, Study of Discrimination Against Persons Born Out of Wedlock, U.N. Doc. E/CN.4/Sub.2/265/Rev. 1 at 184 (1967); Santa Cruz, Racial Discrimination, U.N. Doc. E/CN.4/Sub.2/307/Rev. 1 at 314 (1971). 
porteur to the Sub-Commission, Charles D. Ammoun, was assisted in the preparation of his study on discrimination in education by a note verbale from the Secretary-General to member governments requesting assistance. ${ }^{46}$ Such requests may be so routine as to be ineffective in encouraging ratification. Only twenty countries replied to the Sub-Commission's first inquiry through the Secretary-General. ${ }^{47}$

The Working Group's invitation to states to present oral explanations is an innovation in Sub-Commission practice. Within the human rights field, the Human Rights Committee organized under the U.N. Covenant on Civil and Political Rights and the Racial Committee under the International Convention on the Elimination of All Forms of Racial Discrimination have regularly pursued this approach. ${ }^{48}$ Nevertheless, this practice does not violate the Sub-Commission's rules or terms of reference. Rule 69 of the Rules of Procedure of the Functional Commissions of the Economic and Social Council specifically authorizes the Sub-Commission to "invite any State to participate in its deliberations on any matter of particular concern to that State." 49 Such discussions assist the Working Group and the SubCommission in fulfilling their mandate to make studies and recommendations "concerning the prevention of discrimination of any kind relating to human rights and fundamental freedoms and the protection of racial, national, religious and linguistic minorities . ..." 50 Utilizing these methods, the Group could accelerate ratifications and foster the implementation of human rights treaties. ${ }^{51}$

46. Ammoun, Study of Discrimination in Education, U.N. Doc. E/CN.4/Sub.2/181/Rev. 1 at 177 (1957).

47. By the time of the Working Group's sessions in August 1981, another twenty governments had responded to a renewed inquiry, bringing to a total of forty the number of replies which the Working Group could analyze. See U.N. Doc. E/CN.4/Sub.2/L.785 at 3 (1981).

48. See, e.g., Buergenthal, Implementing the Racial Convention, 12 TEX. INTL L.J. 187, 199-202 (1977); Fischer, Reporting Under the Covenant on Civil and Political Rights: The First Five Years of the Human Rights Committee, 76 AM. I. INTL L. 142 (1982).

49. Functional Rules, supra note 44, rule 69(2) at 17; cf. UNITED NATIONS JURIDICAL YeARBOOK, U.N. Doc. ST/LEG/SER.C/6 at 204 (1968) (U.N. Office of Legal Affairs opinion on whether the Sub-Commission may invite states which are not members of the U.N. to participate in its proceedings). While there was some criticism at the Human Rights Commission of the Sub-Commission for directly addressing governments, such criticism was not focused on the Working Group. The Working Group has only requested information from governments either in writing through the Secretary-General or by inviting governmental representatives to participate in its deliberations. As indicated above, both such efforts are authorized under long-standing practice, ratified by the Commission and ECOSOC, or under the Sub-Commission's rules of procedure, promulgated by ECOSOC.

The Sub-Commission has adopted a number of resolutions which directly addressed governments and sent several telegrams to governments accused of human rights violations. There is both some authority and some reason for doubt about such SubCommission activity. See Haver \& Gardeniers, The Mandate of the Sub-Commission on the Prevention of Discrimination and the Protection of Minorities 14-18 (draft manuscript, August 1981).

50. 9 U.N. ESCOR, Supp. (No. 10) 6, U.N. Doc. E/CN.4/350 (1949).

51. In addition to the ILO and League of Nations systems of reporting, constitutional provisions of some specialized agencies within the U.N. authorize similar procedures. For 


\section{B. The Ability to Encourage Ratification}

The second issue is broader. The Brazilian delegate, Gagliardi, has argued that once an international organization has adopted a treaty and opened it for acceptance, it has no authority to take steps to encourage its entry into force. ${ }^{52}$ However, international organizations exist to promote certain goals which in principle all members share. In pursuit of those goals, organizations adopt conventions and treaties. By encouraging the acceptance of those instruments, international organizations promote the goals of the organization. As noted, United Nations bodies have often encouraged states to ratify instruments. This encouragement does not interfere with a government's determination to ratify a particular treaty, but serves to urge the government to exercise its discretion. ${ }^{53}$

The experience of other international organizations confirms the propriety and efficacy of this technique. Since 1919 the ILO has operated a suc-

example, the World Health Organization Constitution provides that each member will take action relative to the acceptance of a convention or agreement within eighteen months after its adoption by the organization; each member must notify the DirectorGeneral of action taken, and if the convention is not accepted, a statement of reasons for non-acceptance must be submitted. Constitution of THE WORLd Health Organization. entered into force 7 April 1948, 14 U.N.T.S. 185, art. 20 (1948). Similarly, the UNESCO Constitution provides that members must submit conventions and recommendations to authorities for acceptance and must report periodically on the action taken. CONSTITUTION of the United Nations Educational, Scientific and Cultural Organization, arts. IV, VIII, entered into force 4 November 1946, 4 U.N.T.S. 275 (1947); see Ago, La Codification du Droit International et les Problemes de sa Realisation, RECUEIL DETUDES DE DROIT INTERNA. tonal en Hommage a Paul GugGenheim 93, 117 (1968).

Another precursor of the Working Group can be found in the proposal of Netherlands at the 1968 conference to celebrate the twentieth anniversary of the Universal Declaration of Human Rights, to recommend the "establishment of a committee of experts on ratification and acceptance, which would be entrusted with the task of systematic and regular review ... of the state of ratifications of international human rights treaties ...." The committee would be entrusted with "devising ways and means of facilitating the speedy ratification of or accession to international human rights treaties... [and] [o]btaining information from states at regular intervals regarding the steps taken in preparation of ratification...." Final Act of the International Conference on Human Rights, Teheran, 22 April to 13 May 1968, U.N. Doc. ACONF.32/41, at 48 (1968). India proposed an amendment to institute a program of expert assistance to facilitate the speedy ratification of international human rights treaties. Id. at 48 . The resolution and amendment were not voted upon, due to lack of time, but they were transmitted to the U.N. for consideration. Id. at 19.

52. Summary Record of the 1982nd Meeting, U.N. Doc. E/CN.4/SR.1592 at 9 (1981).

53. Such was the conclusion of the United Nations Institute for Training and Research in its analysis of the reporting approach as a method for encouraging ratification of treaties. $O$. Schachter, M. Nawaz, \& J. Fried, TOWARD WIDER ACCEPTANCE OF UN TREATIES 52 (1971) [hereinafter cited as UNITAR STUDY], see also I. Detter, LAW MAKING BY INTERNATIONAL ORGANIZATIONS 168-70 (1965). Detter asserts that an international organization under whose auspices an agreement is negotiated is an "Assistant," but has no right under the instrument. Before a proposed treaty is adopted by member states, it is only a "recommendation" of the organization. Reporting on action taken on the recommendation does not in any way bind a state to ratify the treaty. Sovereign discretion remains intact; actual treaty-making power, the competence to conclude the treaties recommended, can be exercised only by member states. 
cessful reporting mechanism to encourage ratification of its conventions. Pursuant to the ILO Constitution, members are required to submit all ILO conventions and recommendations which they sign to their domestic authorities for acceptance. ${ }^{54}$ Members must report on their compliance with this procedure. ${ }^{55}$ These reports are examined by the International Labour Committee of Experts on the Application of Conventions and Recommendations, and results are published annually, along with experts' comments and observations. ${ }^{56}$ The Governing Body of the ILO selects certain conventions and recommendations on which to concentrate efforts at encouraging acceptance. ${ }^{57}$ The Committee of Experts then periodically requests governments to report upon difficulties which prevent or delay ratification of these conventions. The reports are published and commented upon by the Committee of Experts in an effort to overcome the problems and to promote wider understanding of the difficulties faced by various countries in adopting human rights instruments in the labor field. ${ }^{58}$ Supplementing the formal reporting procedures, informal discussions between ILO staff and government representatives during International Labour Conference sessions have also been very effective in resolving technical difficulties which impede ratification.

The ILO system has been successful. As of 1 January 1981 the 152 member states of the ILO had reported over 4,856 ratifications of the 153 ILO Conventions. ${ }^{59} \mathrm{ILO}$ records contain examples of members acknowledging the valuable assistance offered by the organization in ratifying the instruments. ${ }^{60}$

The League of Nations adopted a similar procedure for encouraging ratification of its conventions. Concerned over the lack of widespread

54. International labour Organisation Constitution, entered into force 1919, revisions entered into force 1946, Art. 19, I 5.

55. Id. If 5(c), 6(c).

56. Such reports are included in the Reports of the Committee of Experts on the Application of Conventions and Recommendations, Report III (Part 3).

57. See, e.g., discussion on the choice of conventions on which Governments should be asked to submit reports for 1980 and 1981. I.L.O. Doc. GB.208/SC/1/6 (1978).

58. Summaries of these reports are submitted to the International Labour Conference each year in Report III (Part 2), Summary of Reports on Unratified Conventions (Article 19 of the Constitution); observations by the Committee of Experts appear in Report III (Part 4).

59. ILO, Chart of Ratifications of International Labor Conventions (1 January 1981).

60. See, e.g., discussion of the Report of the Committee on the Application of Conventions and Recommendations, International Labour Conference, 66th Session, Record of Proceedings (comments of Makabir, Employer's delegate from Trinidad and Tobago, and Vice-Chairman of the Committee) at 42/7 (1980): "The ILO is to be commended on the extent to which it gives assistance to countries, particularly developing countries . . . An impressive system of direct contacts, missions, national and international seminars, fellowships and other means of assistance has been developed over the years, which has been of great help to developing countries .... The progress which has been achieved as a result is a tribute to the efficacy of this assistance." See also id. at 42/13 (remarks of Isacsson, government delegate from Sweden); id. at 42/20 (remarks of Haase, government delegate from the Federal Republic of Germany). 
ratification, the League's Assembly adopted a resolution in 1926 to invite the Council to consider biennial reports on the status of the treaties. ${ }^{61}$ On the recommendation of a committee established to investigate delays in ratification, the Assembly adopted a resolution in 1930 which required the Secretary-General to request signatories not ratifying within one year from the closing of the protocol of signature to report their intentions with respect to the conventions for consideration by the Assembly. If, after five years ratification had not occurred, the Secretary-General was to inquire again into the states' positions. ${ }^{62}$ The reporting procedure and the attention it focused on the importance of ratification resulted in a large increase in ratifications. ${ }^{63}$

Historical records do not explain why the League's system of reporting was not immediately incorporated into the U.N. Charter. ${ }^{64}$ ECOSOC was given the authority to draft conventions for submission to the General Assembly, ${ }^{65}$ to make recommendations to the Assembly and to member states, 66 and to "make arrangements with the members of the United Nations and with the specialized agencies to obtain reports on the steps taken to give effect to its own recommendations and to recommendations on matters falling within its competence made by the General Assembly." 67 In practice, ECOSOC has frequently obtained reports from governments regarding

61. Resolution adopted on 23 September 1926. League of Nations O.J., Spec. Supp. 43 at 27 (1926).

62. Resolution adopted on 3 October 1930. League of Nations O.J., Spec. Supp. 83, at 12 (1930). For discussion on the resolution see League of Nations O.J., Spec. Supp. 84 at 213-17 (1930).

The League of Nations procedure was apparently the result of a Danish initiative supported by the British delegation. League of Nations, Internal Untitled Memorandum to the Secretary-General, 4 February 1935. The League of Nations was joined in 1934 by three new members, including most prominently the U.S.S.R. A debate ensued within the League's Secretariat as to whether the three new members should be queried immediately in early 1935 about their intentions as to ratification of all the treaties which had been formulated under League auspices. There was concern that such an inquiry to the new members might be upsetting in the precarious position of the League at that period and the 1930 resolution gave the Secretary-General discretion as to the timing of inquiries about ratification. In the end, the new members were queried only as to the seven treaties which had recently been established by the League and not all of the older treaties. Id.

63. See F. Wilcox, THe RATIFICATION OF INTERnational CONVENTIONS 133 (1935).

64. Documents of the United Nations Conference on International Organization (UNCIO Documents) (1945); Report of the Preparatory Commission of the United Nations, U.N. Doc. PC/20 (1945); Commentary on the Report of the Preparatory Commission of the United NAtions, Cmd. No. 6734 London (1946). R. Russell, A History OF tHe UNITED Nations Charter (1958); L. Goodrich, E. Hambro \& A. Simons, Charter of the United Nations, Commentary and Documents (3rd and rev. ed. 1969); N. Bentivich \& A. Martin, A Commentary on the Charter of the United Nations (1950); I. Robinson, Human Richis and Fundamental freedoms in the Charter of the United Nations (1946); J. Camara, The RATIFICATION OF International Treaties (1949); Q. Wright, International LaW and the UNITED NATIONS (1960); K. Holloway, MODERN TRENDS IN TREATY LAW (1967).

65. U.N. Charter, art. 62. $\{3$.

66. Id. at 91.

67. Id. at art. $64,91$. 
actions taken on individual resolutions and on groups of recommendations. ${ }^{68}$

The United Nations Institute for Training and Research (UNITAR) study, Toward Wider Acceptance of U.N. Treaties, found that it would be within the competence of the United Nations to institute procedures similar to the ILO system. ${ }^{69}$ The UNITAR study proposed that a committee of experts be established to review systematically states' positions on treaty ratification. ${ }^{70}$ In the field of human rights, the Sub-Commission's Working Group on Universal Acceptance of Human Rights Instruments is just such a body.

\section{PROPOSALS TO ENHANCE THE EFFECTIVENESS OF THE WORKING GROUP}

The Working Group on Universal Acceptance of Human Rights Instruments has just begun its efforts and it may be too soon to assess what contribution it may ultimately make in encouraging treaty ratification. Nevertheless, based upon the initial governmental replies to the Working Group's inquiries about impediments to ratification and the Working Group's early sessions, several observations and suggestions may be offered with a view toward maximizing the success of the Group. First, following the example of the ILO ${ }^{71}$ a few particularly important treaties should be selected for the Working Group's attention. The nine treaties which were identified in the Working Group's authorizing resolution may be too many for efficient consideration during the few days available for meetings. The Working Group might focus on one or two treaties at a time to achieve the greatest effect upon ratifications. For example, the Group might begin with the two Covenants, which are the central human rights instruments, and then proceed to others.

Second, the Working Group might concentrate on one or two issues which frequently delay or prevent ratification. The Group could explore these issues in detail and recommend specific ways in which the United Nations might assist states in overcoming problems. At its first sessions in 1980, the Working Group noted that the extraterritorial criminal responsibility question in the Apartheid Convention troubled many governments, including Australia, the Federal Republic of Germany, the Netherlands, New Zealand, and Sweden. ${ }^{72}$ The Working Group requested through the SubCommission that the Secretary-General make a study of the issue. ${ }^{73}$

68. ECOSOC regularly reports to the General Assembly under article 15(2) of the U.N. Charter on the implementation of recommendations by member governments.

69. UNITAR STUDY, supra note 53 , at 16.

70. $1 d$.

71. See, e.g., I.L.O. Doc. GB.208/SC/1/6 (1978).

72. U.N. Doc. E/CN.4/Sub.2/452, at 3, 6, 9, 12 (1980); U.N. Doc. E/CN.4/Sub.2/452, Add. 4 at 1-2 (1981).

73. Report of the Sub-Commission on Prevention of Discrimination and Protection of Minorities on its Thirty-third Session. U.N. Doc. E/CN.4/1413 at 84-85 (1980). 
There are several other problems which deserve study and attention by the Working Group. For example, the replies of Australia and the United States mentioned the problem of federalism as an impediment to ratification. ${ }^{74}$ The Working Group could determine the extent of this problem and could consult with countries such as Australia and Canada which have overcome federalism difficulties in ratifying some of the principal treaties. The Working Group might convene a discussion in which those countries could offer advice to others encountering similar impediments to ratification, thereby fostering a valuable dialogue among countries. For instance, Canada could explain how it has been able to overcome provincial objections to ratification of the Covenants and the Optional Protocol to the Covenant on Civil and Political Rights. Such a presentation might also assist Australia which has ratified both Covenants but not the Optional Protucol. The United States might be assisted by a discussion of this very difficult problem. While the Departments of Justice and State have attempted to protect state prerogatives as to the human rights treaties, they have not consulted state officials, as Australia and Canada have. Such consultation could clarify which objections states actually have and which might be overcome.

Another problem which the Working Group identified at its 1981 session but did not fully consider concerned the Optional Protocol to the Covenant on Civil and Political Rights. Governments gave the following reasons for nonratification: 1) the title "optional"; 2) the fact that individuals would be entitled to file complaints against states; and 3) the overlap between the procedure in the Protocol and certain regional human rights structures. ${ }^{75}$ Still another obstacle to ratification involved the Slavery Convention. One government expressed concern as to the compulsory jurisdiction of the International Court of Justice. ${ }^{76}$ With respect to the International Convention on the Suppression and Punishment of the Crime of Apartheid, the Working Group noted the reasons often given by states for not becoming parties: "(a) such States had already become parties to the International Convention on Elimination of All Forms of Racial Discrimination; (b) in their view, the definition of the crime of apartheid itself was rather vague; (c) the Convention established extraterritorial criminal jurisdiction for the crime of apartheid; and (d) there was incompatibility between the obligations imposed by the Convention and domestic legislation. Incompatibility with domestic legislation was evoked by States as a reason for not adhering to several other instruments as well." 77

74. U.N. Doc. E/CN.4/Sub.2/452 at 3; U.N. Doc. E/CN.4/Sub.2/452/Add. 2; International Human Rights Treaties, Hearings Before the Senate Comm. on Foreign Relations, 96th Cong., 1st Sess. 26 (testimony of Roberts B. Owen, Legal Advisor, Department of State).

75. U.N. Doc. E/CN.4/Sub.2/452/Add. 3 at 5 (India's response), 8 (Ukrainian Soviet Socialist Republic), 8-9 (U.S.S.R.) (1981).

76. U.N. Doc. E/CN.4/Sub.2/452/Add. 3 at 8-9 (U.S.S.R.).

77. U.N. Doc. E/CN.4/Sub.2/L.785 at 5-6 (1981). 
A third possible approach which the Working Group might consider is to focus on certain nonsubstantive impediments identified by the UNITAR study. ${ }^{78}$ The replies of Rwanda and the United Republic of Cameroon to the Working Group reflected an extreme example of nonsubstantive problems when those governments explained that they could not proceed because they lacked the texts of several human rights instruments. ${ }^{79}$ The SecretaryGeneral promptly supplied the texts.

A number of other governments, including Belgium, the Dominican Republic, Ethiopia, Iran, Italy, Luxembourg, Mexico, Morocco, Rwanda, Spain, Surinam, the United States, and Venezuela indicated that various treaties had been under consideration by administrative or legislative bodies for an extended period. ${ }^{80}$ The UNITAR study found that these delays were often the result of administrative lethargy, a lack of bureaucratic coordination, difficulties in drafting implementing legislation, and a lack of trained personnel to consider ratification issues. ${ }^{81}$ The Working Group could work with these countries to determine whether technical assistance might be useful or whether the UNITAR suggestions for coordinated administrative consideration of treaties might be helpful.

Some of the governments which are currently considering treaties assured the Working Group that they would complete the ratification process "in the near future." 82 The Working Group might contact such governments after an appropriate interval and inquire as to their progress and whether they require assistance.

A fourth approach which the Working Group might consider is patterned after the experience of the ILO. ${ }^{83}$ United Nations staff members could offer technical assistance to countries identified by the Working Group. This approach could be effective in a country such as Papua New Guinea, which indicated in its reply that the Covenants conflict with its customs and laws. ${ }^{84}$ Perhaps technical assistance and a knowledge of the way the Covenants have been applied in countries with similar problems might aid the government of Papua New Guinea in achieving ratification. ${ }^{85}$

78. UNITAR STUDY, supra note 53, at 9.

79. U.N. DoC. E/CN.4/Sub.2/452 at 11,13 (1980).

80. U.N. DoC. E/CN.4/Sub.2/452 at $4,8,9,11$ (1980); E/CN.4/Sub.2/452/Add. 2 (1980); E/CN.4/Sub.2/452/Add. 3 at 3, 5, 6, 7, 10 (1981).

81. UNITAR STUDY, supra note 53, at 81-92.

82. U.N. DoC. E/CN.4/Sub.2/452 at 4, 8, 11 (1980).

83. See notes 54-60 supra and accompanying text.

84. U.N. Doc. E/CN.4/Sub.2/452/Add. 3 at 6.

85. The Working Group's method of offering technical assistance as a means of encouraging ratification follows a recent pattern of ECOSOC and General Assembly activity to pursue U.N. goals through the offer of assistance whenever possible. For example, in 1981 ECOSOC adopted resolution 1981/38 which requested the Secretary-General to consult with governments, other U.N. organs, specialized agencies, nongovernmental organizations, and the Organization of African Unity in drawing a draft plan of action to assist the 
Finally, the Director of the Human Rights Division and his staff could follow the example of the ILO by initiating informal discussions with governmental representatives concerning difficulties in ratifying human rights treaties, using material prepared by the Working Group as a basis for discussion. ${ }^{86}$ The Secretary-General could also initiate discussions with governmental delegations about ratification of the principal human rights instruments, when he receives governmental delegations during General Assembly sessions.

\section{CONCLUSION}

The Working Group on Universal Acceptance of Human Rights Instruments has the potential for encouraging wider ratification of human rights treaties if questions about its competence raised at the thirty-seventh session of the Human Rights Commission do not impede its efforts.

A specific grant of authority to solicit governmental reports and appearances would be clearly preferable to the implied authority the Working Group presently possesses. If doubt remains as to the competence of the Sub-Commission to assign such tasks to the Working Group, either ECOSOC or the General Assembly should give specific authorization to the Working Group. A resolution by one of those bodies would give the Working Group an uncontestable mandate, higher visibility, and consequent increased effectiveness. In the absence of such a resolution, however, the Working Group will continue to operate as it has since its creation. It can continue to encourage communication among states about obstacles encountered in the ratification process and to determine what assistance can be given. The Group's approach combines previously tested reporting techniques with an innovative method for open discussion on human rights treaty ratifications. The present mandate of the Sub-Commission certainly encompasses such an effort.

government of Equatorial Guinea in restoring human rights in that country. See U.N. Doc. E/1981/79 (1981).

Similarly, in 1981 the Working Group on Slavery of the Sub-Commission on Prevention of Discrimination and Protection of Minorities urged the establishment of an interagency panel to provide technical assistance to Mauritania, where there are about 100,000 slaves. The Working Group made references to assistance available from UNCTAD, the ILO, and the experts on slavery appointed by the Commission on Human Rights in 1980. Report of the Working Group on Slavery on its Seventh Session, U.N. Doc. ElCN.4/Sub.2/486 at 7-8 (1981).

The International League for Human Rights urged at the U.N. Commission on Human Rights that the Working Group on Encouraging the Universal Acceptance of Human Rights Instruments provide similar technical assistance in order to promote ratification. See E/CN.4/NGO/318, at 2 (1981).

86. See Alger, Personal Contacts in Intergovernmental Organizations, in D. Princeton, THE UNITED NATIONS SYSTEM AND ITS FUNCTION 104-26 (1968). 
The Working Group's efforts to study problems commonly encountered with ratification of human rights instruments and to provide technical assistance should make it possible to increase the number of states parties to human rights treaties. Other organizations such as the International Committee of the Red Cross and the U.N. High Commissioner for Refugees might also consider such methods for encouraging ratification of their respective treaties. The IL.O and now the Working Group on Encouragement of Universal Acceptance of Human Rights Instruments could provide valuable models for other international organizations concerned with the implementation of important international standards in many areas. 